Int. J. Dev. Biol. 61: 773-783 (2017)

doi: $10.1387 / \mathrm{ijdb} .170192 \mathrm{~ms}$

\title{
Keeping amphioxus in the laboratory: an update on available husbandry methods
}

\author{
JOÃO E. CARVALHO, FRANÇOIS LAHAYE and MICHAEL SCHUBERT* \\ Sorbonne Universités, UPMC Université Paris 06, CNRS, Laboratoire de Biologie du Développement de \\ Villefranche-sur-Mer, Observatoire Océanologique de Villefranche-sur-Mer, Villefranche-sur-Mer, France
}

\begin{abstract}
Cephalochordates, commonly known as amphioxus or lancelets, are small, marine animals that can be found in coastal habitats of temperate, subtropical, and tropical waters. Together with vertebrates and tunicates, the cephalochordates belong to the chordate phylum, whose members are characterized by a number of conserved morphological features, such as a dorsal nerve cord, a notochord, a pharynx, a segmented musculature as well as a post-anal tail. Due to their basal position within the phylum, cephalochordates have become essential models for studying the evolutionary origin and diversification of vertebrates. Here, we present the currently available methods for maintaining and rearing cephalochordates in a laboratory environment, focusing on five species: the European amphioxus (Branchiostoma lanceolatum), the Florida amphioxus (Branchiostoma floridae), the Chinese amphioxus (Branchiostoma belcheri), the Japanese amphioxus (Branchiostoma japonicum), and the Bahamas lancelet (Asymmetron lucayanum). In addition to reviewing the protocols for capture, transport, aquaculture, and feeding of adults, we discuss methods for controlling gonad development and spawning, as well as for growing embryos and larvae. This information is complemented by observations from our animal facility on the European amphioxus (Branchiostoma lanceolatum). In sum, this work summarizes the latest advances in cephalochordate animal husbandry and highlights challenges for improving the use of these animals as laboratory model systems.
\end{abstract}

KEY WORDS: aquaculture, cephalochordate, lancelet, life cycle, model system

\section{Introduction}

Cephalochordates, commonly called amphioxus or lancelets, are small marine animals that are widely distributed in tropical and temperate seas (Holland, 2015). Almost all the described cephalochordate species live in shallow coastal waters with sandy and shell-sand habitats (Holland, 2015). Amphioxus spend most of their lives buried in the substrate of their habitat, filter feeding through jawless, ciliated mouths (Holland, 2015). In cephalochordates, sexes are separate and reproduction takes place during the summer, with the adults swimming up in the water column after sunset to shed their gametes (Holland, 2015). Amphioxus embryos and larvae are planktonic and can be found both inshore and offshore, and their development includes a metamorphosis transforming the larval into the juvenile body plan (Kaji et al., 2013; Paris et al., 2008; Yu and Holland, 2009).

Cephalochordates are one of the three subphyla of the chor- dates, along with tunicates (also known as urochordates) and vertebrates (Bertrand and Escriva, 2011). They were traditionally believed to be the closest living relatives of vertebrates, but recent molecular phylogenetic analyses have identified the tunicates as the actual sister taxon of vertebrates and have positioned the cephalochordates at the base of the chordates (Bourlat et al., 2006; Delsuc et al., 2006). The cephalochordate subphylum comprises about 30 species that are subdivided into three different genera: Branchiostoma, Epigonichthys, and Asymmetron (Holland and Holland, 2010; Kon et al., 2007; Nishikawa, 2004; Poss and Boschung, 1996; Yue et al., 2014; Zhang et al., 2006). Furthermore, recent whole mitochondrial genome analyses indicate that, within

\footnotetext{
Abbreviations used in this paper: A. lucayanum, Asymmetron lucayanum; B. belcheri, Branchiostoma belcheri; B. floridae, Branchiostoma floridae; B. japonicum, Branchiostoma japonicum; B. lanceolatum, Branchiostoma lanceolatum; B. malayanum, Branchiostoma malayanum; EST, expressed sequence tag; Mya, million years ago; rRNA, ribosomal ribonucleic acid.
}

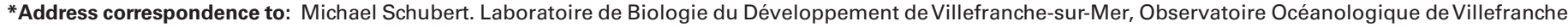

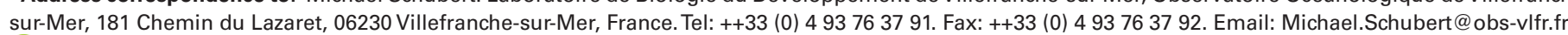
(iD) http://orcid.org/0000-0002-2341-712X
}

Submitted: 8 August, 2017; Accepted: 22 September, 2017.

ISSN: Online 1696-3547, Print 0214-6282 
the cephalochordates, Asymmetron has a basal position and diverged about 42 Mya (million years ago) from the Epigonichthys and Branchiostoma clade, and that Epigonichthys diverged from Branchiostoma about 36 Mya (Igawa et al., 2017). Within the genus Branchiostoma, the different species then separated between 28 and 22 Mya (Igawa et al., 2017).

As members of the chordates, cephalochordate anatomy is characterized by typical chordate features, such as a dorsal hollow nerve cord, a notochord, a pharynx with pharyngeal gill slits, a musculature segmented into myomeres, and a post-anal tail (Bertrand and Escriva, 2011). Amphioxus also possesses a pronephric kidney, a homolog of the vertebrate thyroid gland (the so-called endostyle) as well as an equivalent to the vertebrate adenohypophysis (the so-called pre-oral pit) (Holland et al., 2004; Schubert et al., 2006). Given the anatomical similarities between cephalochordates and vertebrates, members of the cephalochordates have a longstanding history as model organisms studied to understand the origin and morphological diversification of vertebrates (Bettany, 1876; Goldschmidt, 1905; Hatschek, 1893; Yu and Holland, 2009). The advent of modern molecular biology and genomics has further revealed that cephalochordate genomes are surrogates for the ancestral chordate genome, with respect to gene content, exon-intron gene structure, and even chromosomal organization, and hence provide a wealth of information on the evolution of vertebrate genomes (Acemel et al., 2016; Holland et al., 2008; Huang et al., 2014; Putnam et al., 2008). Additionally, recent work has identified cephalochordates as excellent models to study the evolution of both the vertebrate immune system (Yuan et al., 2015) and regenerative processes (Somorjai et al., 2012). Taken together, cephalochordates are thus crucial models for understanding the evolution of both chordates and vertebrates. In this review, we will discuss the different species currently being used as animal model systems for experimental research, focusing on available husbandry methods for maintenance and rearing of adults, embryos, and larvae.

\section{Amphioxus model species}

Amphioxus, since it was first described in the $18^{\text {th }}$ century $(\mathrm{Pal}-$ las, 1774), has become a very important animal model for stydying the origin and diversification of chordates. While most of the early descriptive work on amphioxus development and anatomy was performed using the European species (Branchiostoma lanceolatum), current studies also use other cephalochordate species, such as the Florida amphioxus (Branchiostoma floridae), the Chinese amphioxus (Branchiostoma belcheri), the Japanese amphioxus (Branchiostoma japonicum) or the Bahamas lancelet (Asymmetron lucayanum) (Bertrand and Escriva, 2011; Holland, 2015). In general, adults from different amphioxus species can be distinguished morphologically by assessing the overall body symmetry, as well as by comparing the total number of muscle segments, of dorsal and anal fin chambers, and of pharyngeal slits (Poss and Boschung, 1996).

B. lanceolatum, initially named Limax lanceolatus (Pallas, 1774), was the first amphioxus species to be identified. Despite the fact that this species was erroneously assigned to the mollusks in the early $19^{\text {th }}$ century, Costa (1834) and Yarrell (1836) recognized its affinities with agnathans and fishes, hence identifying $B$. lanceolatum as a chordate (Costa, 1834; Yarrell, 1836). This amphioxus species is widely distributed along European coasts, including the Mediterranean Sea (Fig. 1A) and the population in Argelès-sur-Mer, France, for example, reproduces yearly from the end of May to the end of July (Fig. 1B) (Fuentes et al., 2007). The first embryological studies in amphioxus were carried out on developing B. lanceolatum obtained in Naples, Italy, (Kovalevsky, 1867), followed by a series of other thorough embryological studies (e.g. Cerfontaine, 1906; Conklin, 1932; Conklin, 1933; Hatschek, 1893). Multiple genomic and transcriptomic tools for this species are already available (Acemel et al., 2016; Oulion et al., 2012) and B. lanceolatum is currently being used as a model organism in several European research laboratories.

$B$. belcheriand $B$. japonicum are both found in the West Pacific, where the first amphioxus species, initially named Amphioxus belcheri, was described from samples collected in Borneo in the $19^{\text {th }}$ century (Gray, 1847). Subsequently, a large population of this species, eventually renamed $B$. belcheri, was identified in Xiamen, China (Light, 1923). Several years later, a new amphioxus variety was found in Qingdao, China, and called B. blecheri tsingtauense (Tchang and Koo, 1936). Of note, this novel amphioxus variety is also widely distributed in Japanese waters (Nishikawa, 1981). Recent studies have clarified the status of $B$. belcheriand $B$. blecheri tsingtauense as two distinct species, now called, respectively, $B$. belcheri and $B$. japonicum, both of which can be found in coastal areas of Asia (Fig. 1A) and can even share the same habitats (Fig. 1A) (Zhang et al., 2006). The reproductive period of both species is slightly different, with $B$. belcherifrom Xiamen, China, spawning from July through September and B. japonicum from Kumamoto, Japan, from June through August (Fig. 1B) (Li et al., 2013). Both species were used extensively for developmental studies addressing, for example, the presumptive fates of early cleaving blastomeres or the induction of different embryonic tissues (Tung et al., 1958; Tung et al., 1960; Tung et al., 1961a; Tung et al., 1961b; Tung et al., 1963; Wu and Cai, 1964; Terazawa and Satoh, 1997). Several EST, transcriptomic, and genomic resources are available for both B. belcheri and B. japonicum (Huang et al., 2014; Jin et al., 2017; Suzuki and Satoh, 2000; Yang et al., 2016) and both species are regularly being used as laboratory models, mainly by research groups located in East Asian countries.

$B$. floridae was first collected and described in Tampa Bay, USA, and is also found in several other locations around the Gulf of Mexico (Fig. 1A) (Hubbs, 1922). The natural spawning season of animals collected in Tampa Bay, USA, is from May through September (Fig. 1B) (Holland and Yu, 2004). The first studies on $B$. floridae focused on the determination of the karyotype as well as on adult physiology, including examinations of the circulatory and the excretory systems (Howell and Boschung, 1971; Moller and Ellis, 1974; Moller and Philpott, 1973). In the late 1980s, Holland and Holland (1989) initiated a research program on $B$. floridae fertilization and embryology (Holland and Holland, 1989) and have since pushed this amphioxus model to the forefront of the evolution of development research field. In addition, $B$. floridae was the first amphioxus to have its entire genome sequenced (Holland et al., 2008; Putnam et al., 2008), further highlighting the importance of this particular amphioxus species.

A. lucayanum, also known as the Bahamas lancelet, albeit first described in the Bahamas (Andrews, 1893), is a cosmopolitan cephalochordate species found in various subtropical and tropical habitats in both the Northern and Southern hemispheres (Fig. 1A). 
Several cryptic species of $A$. lucayanum have been described in the Western Indian Ocean, the Central Pacific Ocean as well as the Western Atlantic Ocean (Fig. 1A) (Kon et al., 2006). For the $A$. lucayanum population in the Bahamas, the reproductive season is from April to June and from September to November (Fig. 1B) (Holland, 2011). Adult Asymmetron and Branchiostoma can be distinguished easily on morphological grounds, given that Asymmetron adults are characterized by a single row of gonads running along the right side of the body (Holland and Holland, 2010). Early A. Iucayanum larvae have a pigmented tail fin, comparable to that of early $B$. lanceolatum larvae, which contrasts with the lack of pigmentation in the tail fin of early $B$. floridae larvae (Holland and Holland, 2010). Surprisingly, it has been reported that $A$. Iucayanum and $B$. floridae, members of the genus Asymmetron and Branchiostoma which diverged in the Cenozoic era between 49 and 35 Mya (Igawa et al., 2017), can produce viable hybrid offspring. This represents the most extreme example of hybridization that has so far been demonstrated for multicellular animals (Holland et al., 2015). Given the importance of Asymmetron for understanding the diversification of cephalochordates, a variety of transcriptomic and genomic resources have recently been made available for $A$. lucayanum (Yue et al., 2014; Yue et al., 2016).

\section{Capture and transport}

Amphioxus adults can be collected in the wild by careful sieving of sea floor substratum (Fuentes et al., 2004; Holland and Yu, 2004; Kubokawa et al., 1998). Several different approaches can be used to obtain sea floor substratum and the choice of the method depends mainly on the type of the substratum and the collection depth (Eleftheriou, 2013; Sanders et al., 1965). For sandy environments, which are preferred by cephalochordates, three different collection techniques are available. The first one consists of manually shoveling sand and passing it directly either through a thin mesh (i.e. $1.25 \mathrm{~mm}$ mesh size) or a geology sieve (i.e. $0.71 \mathrm{~mm}$ mesh size). This method is used, when amphioxus adults are found in very shallow habitats (Holland and Holland, 2010; Holland and Yu, 2004; Stokes and Holland, 1996). The second technique makes use of so-called grab samplers, such as Van Venn or Smith-Mclntyre dredges that are attached to a hydraulic winch to lower, trigger, and raise the grab samplers. Collections are carried out by boat and the sample area is typically limited to small areas of less than $0.5 \mathrm{~m}^{2}$ (Fuentes et al., 2004; Henmi and Yamaguchi, 2003; Kubokawa et al., 1998; Kubokawa et al., 2003; Nishino et al., 1999). The third method is adapted to

A

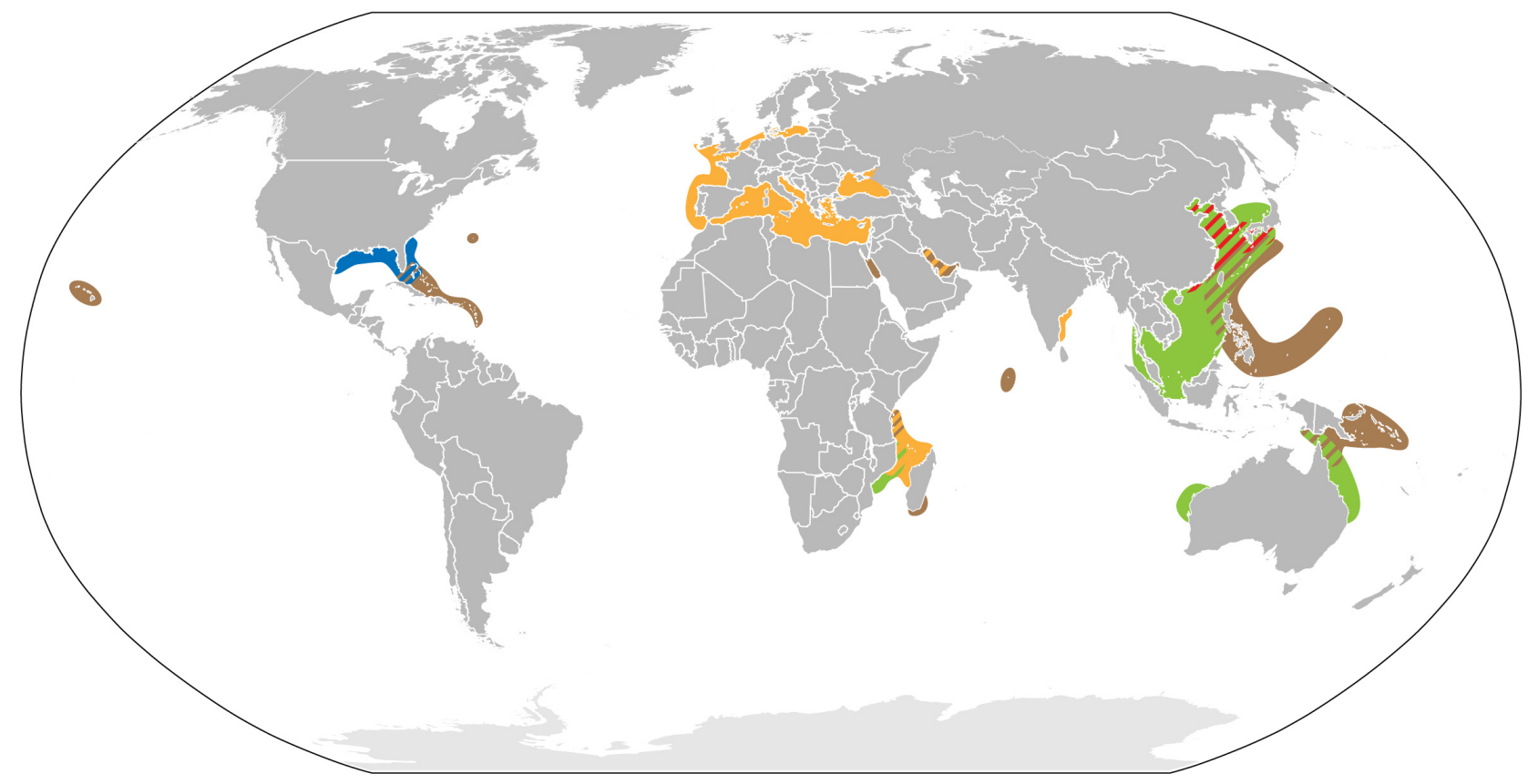

Branchiostoma lanceolatum

Branchiostoma belcheri

Branchiostoma japonicum

V/. Branchiostoma floridae

B

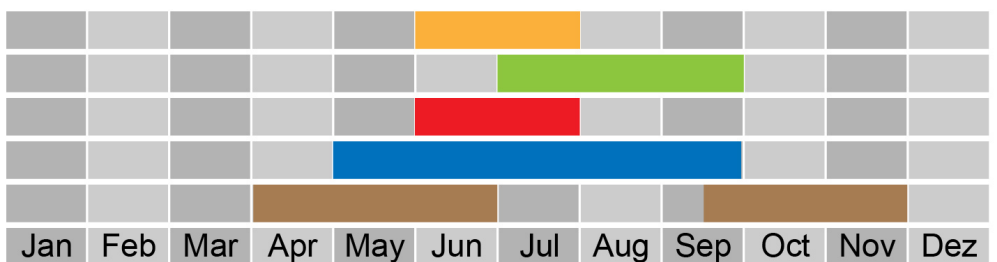

Reproductive period
Fig.1. Amphioxus model species. (A) Global distribution. The distributions are based on species collection data reported by Kon et al. (2006) and Poss and Boschung (1996). (B) Natural spawning season of amphioxus species. The reported reproductive periods for different amphioxus species are indicated following the color code in (A). Data are based on reports in Fuentes et al. (2007), Holland (2011), Holland and Yu (2004), and Li et al. (2013). 
collect larger amounts of substratum and is based on benthic (i.e. bottom) trawling approaches using specifically adapted CharcotPicard, Sanders or other sediment dredges (with a net opening of at least $60 \mathrm{~cm} \times 20 \mathrm{~cm}$ and a mesh size of $0.05 \mathrm{~mm}$ ). The mouth of the net is held open by a solid metal beam and is attached to two shoes, which are solid metal plates welded to the ends of the beam that dredge the seabed when dragged by a boat (Fuentes et al., 2004; Kubokawa et al., 1998; Sanders et al., 1965). Once the sea floor substratum has been obtained, sieves are generally used to separate out amphioxus adults of different sizes (Fuentes et al., 2004; Kubokawa et al., 1998).

Once isolated, adult amphioxus can rather easily be transported over both short and long distances as long as some basic packaging conditions are met. These consist of controlling (1) the total number of animals relative to the total volume of substratum, (2) the temperature, (3) the ratio of air to seawater, and (4) the luminosity (Theodosiou et al., 2011). In general, it is preferable to ship and transport amphioxus adults with sand, since individuals will be less disturbed by movements while burrowed in the sand (Theodosiou et al., 2011). To limit stress induced by transportation, it is also very important not to overcrowd animals and to keep the temperature stable, matching the temperature of the natural environment of the amphioxus species, for example, by using temperature-controlled boxes or by adapting the ambient temperature during transportation (Theodosiou et al., 2011). Moreover, it is important to provide sufficient air supply for the amphioxus adults within the shipment container (Theodosiou et al., 2011). Finally, if transporting ripe animals, constant light conditions are preferable to avoid spontaneous spawning during the shipment, which can be achieved either by using transparent containers or by providing artificial illumination within the shipment box (Holland and Yu, 2004; Theodosiou et al., 2011). For instance, transparent $1.5 \mathrm{~L}$ flasks containing $3 \mathrm{~cm}$ of sand and $750 \mathrm{~mL}$ of seawater can be used to transport up to 10 individuals. Alternatively, up to 20 amphioxus adults can be transported in translucent $3 \mathrm{~L}$ plastic sleeves with $3 \mathrm{~cm}$ of sand and at least $1 \mathrm{~L}$ of seawater. A transparent 20 L plastic carboy with $10 \mathrm{~cm}$ sand and about 10 to $12 \mathrm{~L}$ of seawater can be used to transport up to 150 individuals. Temperature control during shipment can be assured by using well-isolated Styrofoam boxes or thermostatic containers that allow the adjustment of the transportation temperature (BenitoGutiérrez et al., 2013; Theodosiou et al., 2011).

\section{Aquaculture}

In order to implement amphioxus as an exploitable animal model system, great efforts have been undertaken, in the course of the last few years, to generate tools for maintaining and reproducing amphioxus in captivity in the laboratory. The prospects of obtaining embryos on a daily basis, of overcoming the seasonality of the reproductive period, and of completing the life cycle in a controlled environment have motivated several research groups to invest in the establishment of amphioxus aquaculture facilities. More or less sophisticated aquaculture protocols to maintain amphioxus adults have been developed for all five amphioxus species currently used as model systems, i.e. B. lanceolatum (Benito-Gutiérrez et al., 2013; Fuentes et al., 2004; Fuentes et al., 2007; Somorjai et al., 2008; Theodosiou et al., 2011), B. belcheri and B. japonicum (Li et al., 2012; Li et al., 2013; Li et al., 2015; Wang et al., 2006; Yasui et al., 2007; Yasui et al., 2013; Zhang et al., 2007), and B. floridae and A. lucayanum (Holland et al., 2015; Holland and Holland, 2010; Holland and Yu, 2004). These protocols employ a variety of different approaches, including the use of natural or artificial seawater and of different temperature regimes. In captivity, adults of temperate species, such as $B$. lanceolatum and $B$. japonicum, are thus maintained at 14 to $21^{\circ} \mathrm{C}$, while adults of subtropical species, such as $B$. floridae, $B$. belcheri, and $A$. lucayanum, are kept at temperatures above $24^{\circ} \mathrm{C}$ (Benito-Gutiérrez et al., 2013; Fuentes et al., 2004; Fuentes et al., 2007; Holland and Holland, 2010; Li et al., 2012; Li et al., 2013; Li et al., 2015; Somorjai et al., 2008; Theodosiou et al., 2011; Wang et al., 2006; Yasui et al., 2007; Yasui et al., 2013; Yong and Yu, 2016; Zhang et al., 2007). Albeit their inherent differences, the currently used amphioxus animal
A

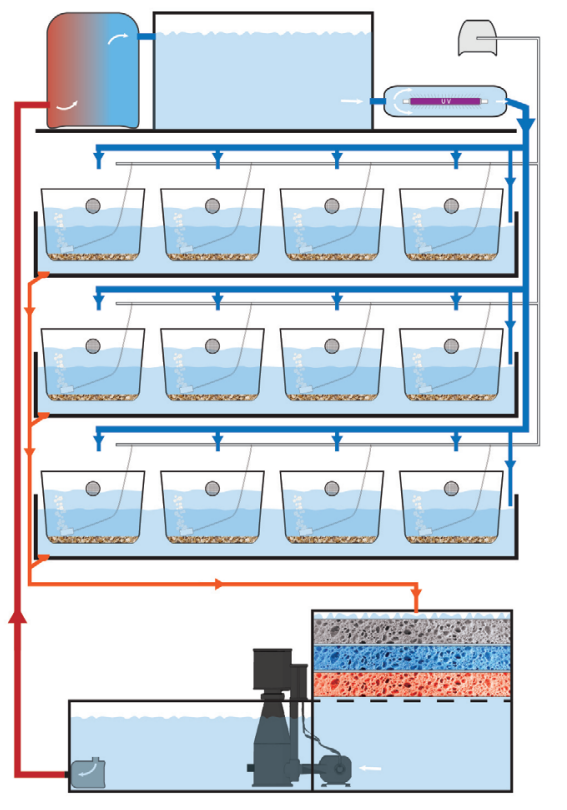

B

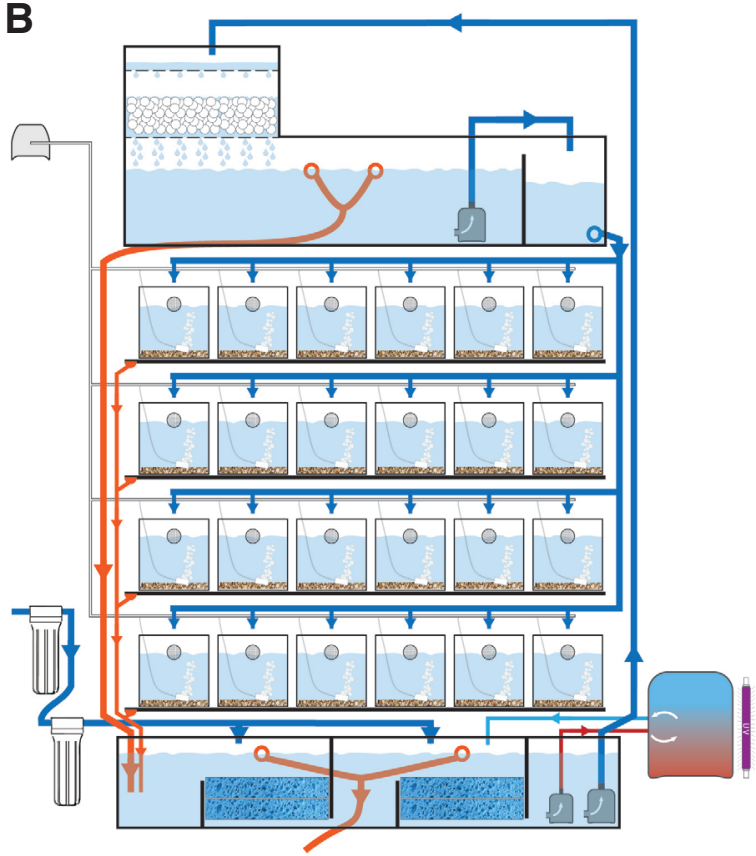

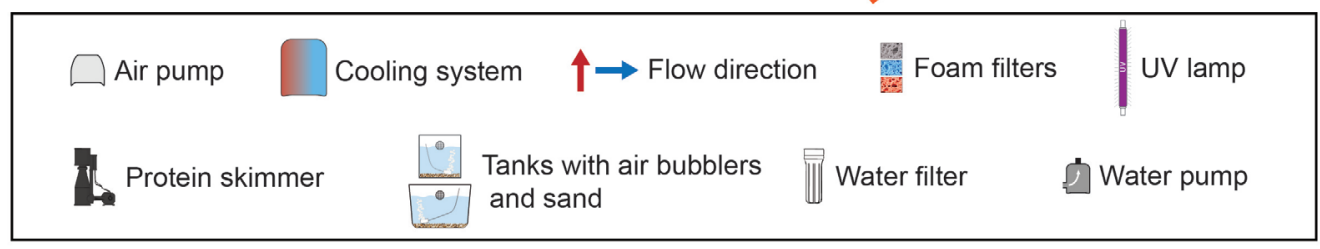

Fig. 2. Main types of amphioxus aquaculture systems. (A) Schematics based on Benito-Gutiérrez et al. (2013). (B) Schematics based on Theodosiou et al. (2011). 
husbandry systems can be divided into two main types (Fig. 2). The first type is based on the use of individualized tanks that are alimented by a reservoir and placed into a water bath that is used to avoid temperature fluctuations induced by room temperature changes (i.e. similar to a Xenopus aquarium system) (Fig. 2A) (Benito-Gutiérrez et al., 2013; Somorjai et al., 2008). The second type is also based on the use of individualized tanks that can be alimented by a reservoir, but the individual tanks are not incorporated into a larger water bath system (i.e. similar to a zebrafish aquarium system) (Fig. 2B) (Theodosiou et al., 2011; Yasui et al., 2007). Ideally, both aquaculture system types should be operated with a constant renewal of natural seawater, although limited regular water changes have already been successfully implemented in amphioxus facilities of landlocked laboratories (Benito-Gutiérrez et al., 2013; Theodosiou et al., 2011).

The amphioxus animal system in Villefranche-sur-Mer, France, is a modified version of a previously described aquarium setup (Theodosiou et al., 2011) that is based on the second model type (built by Müller + Pfleger $\mathrm{GmbH} \& \mathrm{Co}$. KG). The facility is located in a completely dark room, whose ambient temperature can be regulated (from 10 to $20^{\circ} \mathrm{C}$ ). In this room, two independent aquarium structures were built, each of which with a maximum capacity of 24 $5 \mathrm{~L}$ aquariums. Each aquarium system consists of an upper and a lower seawater reservoir and four rows with aquarium tanks (Fig. 2B). The two systems are completely independent in terms of seawater supply, temperature, and light control. To further increase the modularity of the systems, the seawater supply and light regimes in each of the 4 rows of each system can be controlled independently (ProfiLux 3.1T attached to Profilux extension box 2 from GHL). Blinds installed at the level of each row allow independent access and avoid light contamination of neighboring rows. Each aquarium tank is equipped with air bubblers and a thin layer of sand, which is changed and sterilized once a month. Of note, although the use of air bubblers is recommended, they might be dispensable for some amphioxus animal facility setups ( $\mathrm{Li}$ et al., 2012; Li et al., 2013). The two aquarium systems are generally run in a semiopen configuration with a constant influx into the lower reservoir of natural seawater, pre-filtered by two $25 \mu \mathrm{m}$ filters. The seawater in the lower reservoir passes through four foam filters before being pumped into the top reservoir, which contains a trickle filter system. Simultaneously, seawater in the lower basin is constantly pumped through a temperature controller equipped with an internal UV light (TECO-TR30) for sterilization. From the top reservoir, seawater is constantly distributed into the individual tanks, except during the feeding period (twice a day for 3 hours each).

\section{Feeding}

Amphioxus adults have the capacity to filter and ingest a large spectrum of particle sizes (from 0.062 to $100 \mu \mathrm{m}$ ) (Ruppert et al., 2000), suggesting that their diet includes everything from bacteria to phytoplankton, and potentially even small zooplankton. Due to this indiscriminate filtering capacity, amphioxus may play a fundamental trophic role in coastal food webs (Ruppert et al., 2000). So far, only a single study has addressed the natural diet of amphioxus, more specifically of $B$. belcheri and $B$. malayanum populations in Hong Kong waters (Chen et al., 2008). The results of this work support the notion that amphioxus adults indeed consume a wide variety of organisms, including microbes, bacteria, microalgae, marine fungi, diatoms, dinoflagellates, and zooplankton (Chen et al., 2008). Given that amphioxus adults also ingest detritus, they can be classified as omnivores (Chen et al., 2008). A massive 16S rRNA sequencing analysis of feces further highlighted the importance of bacteria as dietary source for amphioxus adults, but also identified the digestive tract as an important resource for understanding the ecology of amphioxus living in different habitats (Pan et al., 2015).

Contrasting the results obtained from wild animals, amphioxus adults kept in the laboratory are usually fed a mix of different algal, i.e. phytoplankton, species. Typically, brown algae (e.g. Isochrysis sp. or Pavlova sp.) are mixed with green algae (e.g. Dunaliella sp. or Tetraselmis sp.), and diatoms (e.g. Thalassiosira sp. or Chaetoceros sp.) (Desdevises et al., 2011; Holland et al., 2015; Li et al., 2012; Yasui et al., 2007; Yasui et al., 2013; Yu and Holland, 2009). This algal diet can further be complemented with artificial supplements, such as iodine (JBL), Sailboat shrimp flakes (Bonasse Biochemistry Feed Company), Liquifry (Interpret), Microfeast PZ-20 (Salt Creek), Nutrimarin (GroTech), Planktomarine (GroTech), Preis-Microplan (Preis-Aquaristik), Roti-Rich (Florida Aqua Farms), MicroFood (Tetra) or Vitamino (GroTech) (BenitoGutiérrez et al., 2013; Fuentes et al., 2004; Li et al., 2012; Li et al., 2013; Theodosiou et al., 2011).

Intriguingly, amphioxus adults can be maintained in the laboratory even without feeding, but this obviously compromises their capacity to refill gonads and reduces the overall spawning efficiency (Fuentes et al., 2004; Li et al., 2012; Somorjai et al., 2008). Amphioxus adults should thus be supplied with food at least once a day $(30,000$ to 80,000 cells of fresh algae per tank) (Benito-Gutiérrez et al., 2013; Li et al., 2013; Theodosiou et al., 2011). In contrast to adults, nothing is known about the feeding behavior of amphioxus larvae in their natural habitat. In the laboratory, amphioxus larvae can be raised on a daily diet consisting of a mix of diatoms, green, and brown algae $(5,000$ to 150,000 cells per culture, depending on the culture system, see below) (Urata et al., 2007; Wu et al., 2000; Zhang et al., 2007). Nevertheless, this dietary regime seems ineffective for raising larvae of some amphioxus species, such as A. lucayanum (Holland and Holland, 2010). Additional studies will thus be needed to fully understand the dietary needs of both developing and adult amphioxus.

\section{Gonad development and spawning}

One major challenge for keeping long-term cultures of amphioxus is to create a permissive environment for newly metamorphosed juveniles and spawned-out adults to develop and maturate gonads (Benito-Gutiérrez et al., 2013). Due to a lack of information on the ecological parameters controlling these processes in wild populations, only a very limited set of conditions have been tested on amphioxus in captivity (Benito-Gutiérrez et al., 2013). For B. lanceolatum, for example, several different alimentary regimes have been assayed and it was shown that constant feeding with a rich diet is required to stimulate gonadal development sufficient for subsequent spawning (Benito-Gutiérrez et al., 2013; Fuentes et al., 2004). Furthermore, studies in B. belcheri have highlighted that the quality of seawater and settlement substratum as well as the number of animals per tank affect both the development of gonads and the spawning probability of a given laboratory population ( $\mathrm{Li}$ et al., 2012; Zhang et al., 2007).

Another shortcoming of the reproduction of amphioxus is as- 
sociated with the efficiency of the available on-demand spawning protocols. In $B$. lanceolatum, spawning can be induced on any given day during the breeding season by applying a simple 24-hour heat shock at $23^{\circ} \mathrm{C}$ (Fuentes et al., 2004; Fuentes et al., 2007; Theodosiou et al., 2011). This technique can also be applied to de-phased $B$. lanceolatum adults that have been matured and induced to spawn outside the natural breeding season (BenitoGutiérrez et al., 2013). Nevertheless, continuous spawning of $B$. lanceolatum in the laboratory has not yet been documented, and it thus remains possible that each $B$. lanceolatum individual only spawns once or twice per reproductive period (Fuentes et al., 2004). In contrast, for other amphioxus species, it seems more difficult to induce spawning on a specific day. For instance, although $B$. belcheri and $B$. japonicum can also be induced to spawn using a thermal shock, the obtained spawning efficiency is much lower than what has been reported for B. lanceolatum (Li et al., 2013). Furthermore, B. japonicum seems to behave like B. lanceolatum, with each individual spawning only once or twice during a given reproductive season (Li et al., 2013; Yasui et al., 2013). B. belcheri, however, is able to spawn consecutively several times a year, although the time between spawnings is highly variable between individual amphioxus adults, ranging from two to six months (Li et al., 2012; Li et al., 2013). B. floridaewas initially described to spawn after a $50 \mathrm{~V}$ electric shock of $10 \mathrm{msec}$ (Holland and Yu, 2004), but this technique has now been abandoned and spawning is induced by elevating the temperature by $5^{\circ} \mathrm{C}$ for 24 to 36 hours. Like for $B$. belcheri and $B$. japonicum, this heat shock methods can induce spawning, albeit less efficiently than in B. lanceolatum (Holland et al., 2015). Furthermore, as described for $B$. belcheri, a given $B$. floridae adult can spawn several times a year, independently of their natural spawning period, with a notable increase in spawning probability around new and full moon (Holland et al., 2015). For

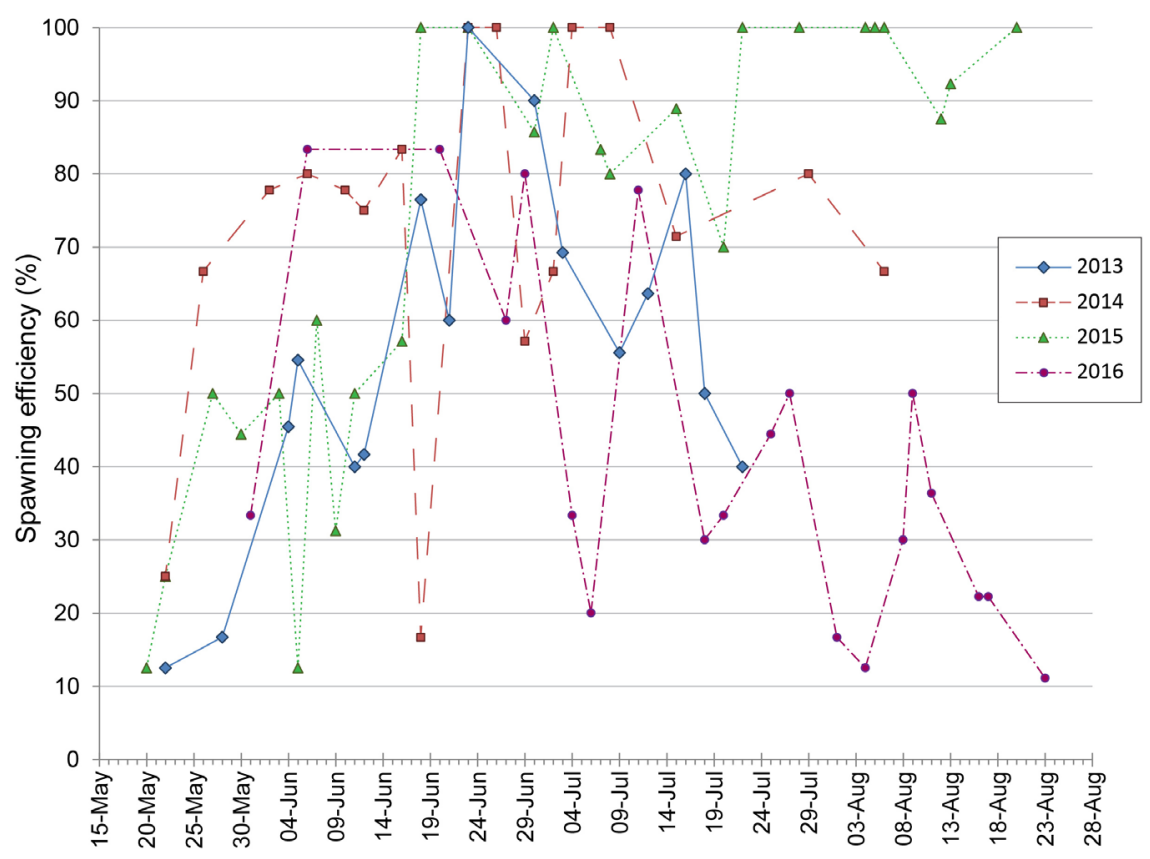

Fig.3. Spawning efficiency of Branchiostoma lanceolatum adults in captivity. The percentage of successfully induced spawning for each temperature shock-induced spawning day of the 2013, 2014, 2015, and 2016 reproductive seasons is indicated.
TABLE 1

SELECTED SPAWNING-RELATED DATA FOR THE SPAWNING SEASONS 2013, 2014, 2015, AND 2016 FOR BRANCHIOSTOMA LANCEOLATUM ADULTS KEPT IN THE AMPHIOXUS FACILITY IN VILLEFRANCHE-SUR-MER, FRANCE

\begin{tabular}{|c|c|c|c|c|}
\hline Season & 2013 & 2014 & 2015 & 2016 \\
\hline Number of spawning days & 16 & 17 & 26 & 20 \\
\hline Number of shocked animals & 175 & 132 & 233 & 154 \\
\hline Number of animals that spawned & 102 & 93 & 168 & 60 \\
\hline Global spawning efficiency (\%) & 58.29 & 70.45 & 72.10 & 38.96 \\
\hline $\begin{array}{l}\text { Ripe animals from previous years - } \\
\text { in captivity (\%) }\end{array}$ & $\mathrm{N} / \mathrm{A}$ & $N / A$ & 27.00 & 30.37 \\
\hline $\begin{array}{l}\text { Spawning efficiency of ripe animals from } \\
\text { previous years - in captivity (\%) }\end{array}$ & $\mathrm{N} / \mathrm{A}$ & $\mathrm{N} / \mathrm{A}$ & 32.43 & 23.33 \\
\hline
\end{tabular}

N/A: not available.

A. lucayanum, no data on gonadal development have so far been reported (Holland, 2011), but observations in both the field and captivity suggest that, when $A$. lucayanum adults are kept at constant, warm temperatures, they spawn repeatedly and regularly within a given year, with the timing of the spawnings being determined by the lunar cycle (Holland, 2011; Holland et al., 2015).

Asummary of the spawning efficiencies of $B$. lanceolatum adults from the amphioxus animal facility in Villefranche-sur-Mer, France, in the years 2013, 2014, 2015, and 2016 is provided in Table 1. The animals kept in this facility are collected once per year (during the month of April) on a single day by dredging in Argelès-sur-Mer, France. After retrieval from the sand, animals with clearly visible gonads are transported to Villefranche-sur-Mer, France, by car. The first two weeks following the arrival of the $B$. lanceolatum adults in Villefranche-sur-Mer, France, the animals are kept in $20 \mathrm{~L}$ tanks with sand, constant aeration as well as seawater supply and are being fed daily. The light cycle of 14/10 hours (light/dark) is inverted upon arrival in the facility, with nightfall being at 8:00 am, but this time can be adjusted according to specific experimental requirements. After the two-week quarantine, the condition of each adult is checked individually, and the healthy adults are transferred to 5 $\mathrm{L}$ tanks with sand and constant aeration (Fig. 2B). The optimal number of amphioxus adults per $5 \mathrm{~L}$ tank is between 10 and 20 . The first spawnings are subsequently induced after an additional adaption period of two weeks.

When considering the overall spawning efficiency obtained with this facility, on 79 spawning days in the years 2013, 2014, 2015, and 2016, 694 individuals were shocked, of which 423 spawned, resulting in an overall spawning efficiency of about $60 \%$. The spawning efficiencies of $B$. lanceolatum adults in the course of a given spawning season, 2013, 2014, 2015 or 2016, are shown in Fig. 3. The highest spawning efficiency was obtained in mid-June in 2013, in mid-June to beginning of July in 2014, and from mid-June to mid-August in 2015 (Fig. 3). Contrasting the results obtained in 2013, 2014, and 2015, the spawning efficiency in 2016 was highly variable and generally lower than in the 
Fig. 4. Temperature measurements and artificial light cycles in the Branchiostoma lanceolatum animal facility. Three daily seawater temperature measurements were carried out in the amphioxus animal facility from the beginning of the 2015 spawning season (May 2015) through the end of the 2016 spawning season (August 2016). The highest (red) and lowest (blue) temperatures for a given day are plotted. The light cycles for a given month are represented by a circle with yellow (light) and black (dark) compartments. The numbers within each compartment correspond to the daily hours (h) of presence or absence of light. The months, during which the facility was run on an inverted light cycle, are indicated.

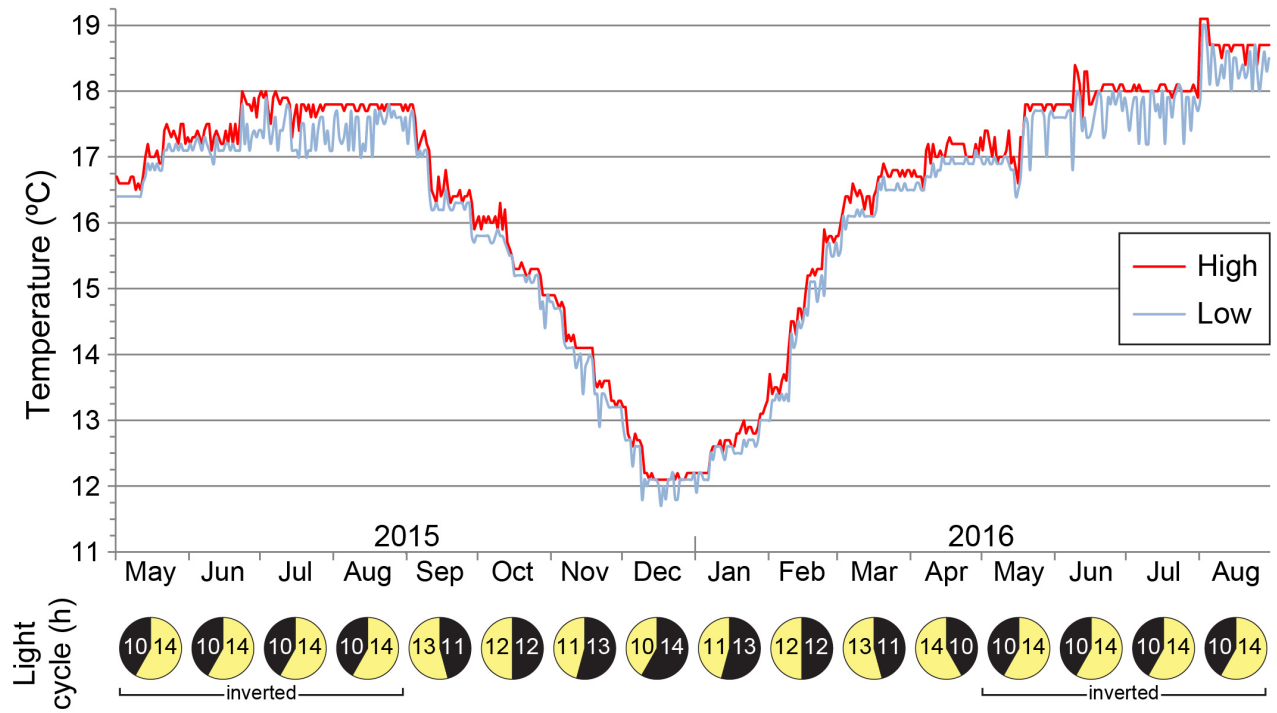

three preceding spawning seasons (Fig. 3). For the seasons 2013, 2014 , and 2015, we estimate that the progressive increase in spawning efficiency (from 58.29\% in 2013 to $72.10 \%$ in 2015) is due to a gradual optimization of the animal husbandry conditions (for example, light and temperature regimes as well as feeding conditions). In this respect, the results obtained in 2016 are particularly stunning, as they strongly deviate from the trend of the preceding years, despite identical photoperiods, temperatures, and feeding conditions (Fig. 4). The only difference is a temperature increase of one degree in August 2016, in an effort to stimulate the overall spawning behavior of the B. lanceolatum adults (Fig. 4). We thus interpret the spawning results of the 2016 season $(38.96 \%$ of spawning efficiency) as a population effect that might be correlated with specific environmental conditions that the adults experienced in their habitat in Argelès-sur-Mer, France, ahead of their collection. While this hypothesis is highly speculative, it nonetheless suggests that improvements of amphioxus animal husbandry conditions will ultimately also require a much more detailed understanding of the ecological cues that control the amphioxus life cycle.

To stabilize the $B$. lanceolatum adult cultures and maintain them after the end of the spawning season, the temperature and light regimes in the facility were altered to simulate the environmental conditions in the wild (Fig. 4). Starting in September 2014, a winter-like cold period was thus simulated by slowly decreasing the seawater temperature until the month of December. Thereafter, the seawater temperature was slowly increased again until reaching a summer-like temperature by the end of April. Along with the temperature changes, the photoperiod was also incrementally altered from a 14/10 hours light/dark period during the spawning season to a 10/14 hours (light/dark) cycle during the month of December only to return to the initial 14/10 hours (light/dark) period in April (Fig. 4). During this period, the animals were fed either once (2014 to 2015) or twice (2015 to 2016) a day with a mixture of brown (Tisochrysis lutea) and green algae (Tetraselmis sp.), supplemented with the artificial food complement Microfeast PZ-20 (Salt Creek). Using this approach, 27\% (2014 to 2015) and $30.37 \%$ (2015 to 2016) of the spawned-out B. lanceolatum adults kept in the facility after the end of the spawning season refilled their gonads ahead of the next spawning season (Table 1). Of note, the spawning efficiency of these animals was significantly lower than that of the animals collected in Argelès-sur-Mer, France, reaching only $32.43 \%$ in 2015 and $23.33 \%$ in 2016 (Table 1). While these results demonstrate that $B$. lanceolatum adults can indeed refill gonads in captivity (Benito-Gutiérrez et al., 2013), they also show that additional work is needed to further optimize the implemented animal husbandry protocols.

\section{Embryo and larval cultures}

Following the spawning of amphioxus adults, fertilization can be achieved in vitro by simply adding a few drops of sperm to eggs collected in a Petri dish (Holland and Yu, 2004). Within minutes after adding sperm, the fertilization envelope starts expanding from the egg (Holland and Holland, 1989). Although amphioxus embryos can be raised rather easily in Petri dishes of different sizes without the need, for example, of specific aeration techniques, it is essential to avoid overcrowding of the cultures (Holland and Yu, 2004). After several cleavage rounds, a blastula forms that subsequently develops into a gastrula (Hirakow and Kajita, 1990; Hirakow and Kajita, 1991; Kovalevsky, 1867). At the onset of neurulation, the embryos start spinning inside the fertilization envelope by ciliary undulations and, after hatching, use this mode of locomotion to swim to the surface of the water (Holland and Yu, 2004). Hatched neurulae elongate from a tail bud and start developing distinctive pharyngeal structures (Holland and $\mathrm{Yu}, 2004)$. Once the mouth of the larva has been formed, together with the $1^{\text {st }}$ gill slit and anus (Hirakow and Kajita, 1994; Stokes and Holland, 1996), the animals need to be fed with algae, which also requires the initiation of additional cleaning protocols for the cultures (Holland and $\mathrm{Yu}$, 2004). As development proceeds, the larvae add gill slits at the posterior end of the pharynx (Hirakow and Kajita, 1994; Stokes and Holland, 1996). The end of larval life is determined by the onset of metamorphosis, the timing of which depends on the amphioxus species. For instance, $B$. japonicum larvae metamorphose with 16 to 18 gill slits, about 60 days after fertilization at 23 to $25^{\circ} \mathrm{C}$ (Urata et al., 2007), B. lanceolatum with at least 14 gill slits, 45 to 50 days after fertilization at $23^{\circ} \mathrm{C}$ (Fuentes et al., 2007; Wickstead, 1967), and $B$. floridae with 9 to 10 gill slits, 23 to 32 days after fertilization 
at $30^{\circ} \mathrm{C}$ (Holland and $\mathrm{Yu}, 2004$ ).

Although amphioxus embryos and larvae can be raised through metamorphosis (Kaji et al., 2013; Stokes and Holland, 1995), the limiting factor for obtaining filial generations of amphioxus nonetheless remains the low survival rate (Bertrand and Escriva, 2011). This is the reason why, although $B$. lanceolatum embryos can be cultured through metamorphosis in captivity (Desdevises et al., 2011; Paris et al., 2008), a complete life cycle has not yet been completed in the laboratory. In contrast, massive embryonic cultures of both $B$. belcheri and $B$. japonicum have successfully been used to create long-term amphioxus cultures spanning several generations (Li et al., 2017; Wang et al., 2006; Yasui et al., 2007; Yasui et al., 2013; Zhang et al., 2007). Moreover, it has been shown that, when maintained in natural seawater with sand, at least the $B$. belcheri cultures can be raised in the laboratory in phase with the natural life cycle (Zhang et al., 2007).

To date, three different approaches to obtain amphioxus juveniles have been described in detail. Larvae were either raised in large Petri dishes (Fig. 5A) (Holland and Yu, 2004; Stokes and Holland, 1996) or in large tanks with (Fig. 5B) (Wu et al., 2000) or without (Fig. 5 C,D) sand (Urata et al., 2007; Yasui et al., 2007; Zhang et al., 2007). Once B. floridae larvae start feeding, they can be grown in $14 \mathrm{~cm}$ Petri dishes, but have to be cleaned every day by being transferred into a new, clean dish (Holland and Yu, 2004; Stokes and Holland, 1996). This method is ideally used to raise only a few dozen larvae and has not been used to grow juveniles until they reach sexual maturity (Holland and Yu, 2004; Stokes and Holland, 1996). In contrast, the use of massive cultures of $B$. japonicum larvae, kept in $600 \mathrm{~L}$ tanks with a $5 \mathrm{~cm}$ layer of sand and with half the volume of seawater being changed daily, yielded a survival rate of $5.5 \%$ through metamorphosis and of $0.7 \%$ to reach sexual maturity (Wu et al., 2000). Of note, $B$. japonicum larvae that stopped developing at the 3 gill slits stage died within a few days, suggesting that passing this developmental stage is of special importance for reaching metamorphosis $\mathrm{Wu}$ et al., 2000). Protocols for massive cultures of both B. belcheri and $B$. japonicum larvae have further been reported in opaque $20 \mathrm{~L}$ basins without sand, but with continuous aeration (Zhang et al., 2007). Before feeding, the seawater in these cultures was partly replaced by filtration and dead algae and feces were purged weekly by moving the developing larvae into a clean basin (Zhang et al., 2007). After 30 days of culture, a $1 \mathrm{~cm}$ layer of sand was added to allow larval settlement and metamorphosis (Zhang et al., 2007). Following metamorphosis, the juveniles were cultivated using adult conditions ( 20 to $50 \mathrm{~L}$ tanks, with sand and without aeration) (Zhang et al., 2007). Ultimately, $3 \%$ of the cultured $B$. belcheri and $B$. japonicum larvae gave rise to sexually mature adults (Zhang et al., 2007). B. japonicum larvae have further been raised in aerated $33 \mathrm{~L}$ glass tanks without sand, with the cultures fed daily and the seawater changed weekly (Urata et al., 2007; Yasui et al., 2007). Although the survival rate to sexual maturity has not been quantified, it was described as "not high" (Urata et al., 2007; Yasui et al., 2007).

In an effort to significantly increase the overall survival rate of developing amphioxus in culture, a novel system for growing $B$. lanceolatum embryos and larvae has been established in Villefranche-sur-Mer, France. The module is based on a nursery tank system developed for cultures of the cnidarian Clytia hemisphaerica (Momose, 2010) and has a cylindrical shape, a flat top, and a volume of $5.8 \mathrm{~L}$ (Fig. 5E). The cylindrical wall is perforated by a little tube that serves as air supply when connected to an air pump (Fig. 5E). When properly configured, air supply creates bubbles that in turn create a circular current within the tank that supports active larval movements and avoids deleterious larval contacts with the aquarium walls and the air-water interphase (Holland and Holland, 2010). In a preliminary test, a large population of $B$. lanceolatum larvae was kept in this nursery module for 40 days. The animals were fed with live algae (Tisochrysis lutea) twice a day, two thirds of the seawater was replaced daily by aspiration, and the culture was moved to a clean aquarium once
A

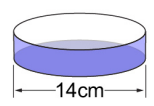

B

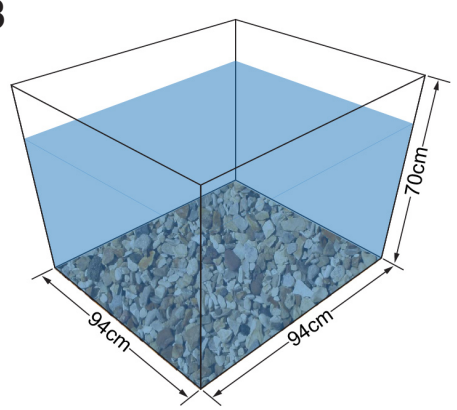

Petri dish
Tank (600L)
C

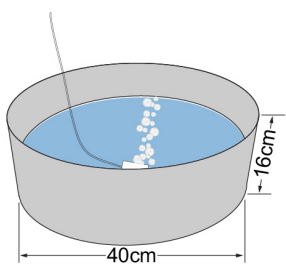

Basin (20L)

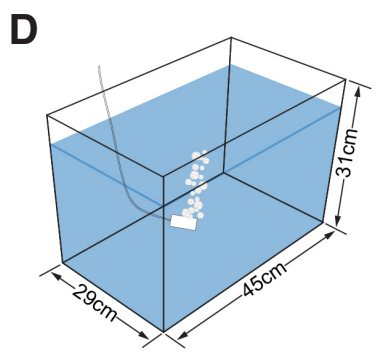

Tank (33L)
E

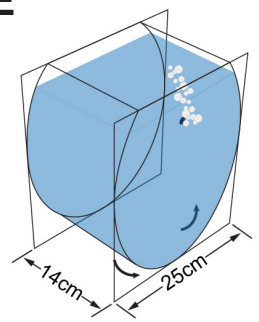

Tank (5.8L)
Fig. 5. Culture systems for Branchiostoma larvae. (A) $14 \mathrm{~cm}$ Petri dish with seawater changed every day, used to raise $\mathrm{B}$. floridae larvae (Holland and Yu, 2004; Stokes and Holland, 1996). (B) 600 $L$ tank with sand at the bottom and with half of the total seawater changed daily, used to raise $\mathrm{B}$. japonicum larvae (Wu et al., 2000). (C) 20 L basin with continuous aeration, seawater changed every day, and, after 30 days of culture, addition of a 1 $\mathrm{cm}$ layer of sand, used to raise B. belcheri and B. japonicum larvae (Zhang et al., 2007). (D) $33 \mathrm{~L}$ tank with continuous aeration and seawater changed weekly, used to raise B. japonicum larvae (Urata et al., 2007; Yasui et al., 2007). (E) 5.8 L cylindrical tank with continuous aeration creating an internal circular flux (indicated by the curved arrows), with two thirds of the seawater changed daily, used to raise $\mathrm{B}$. lanceolatum larvae. 
a week by carefully transferring the animals in small volumes of water. Encouragingly, we found that about 60 to $80 \%$ of the larvae survived the experiment and, based on the number of live animals observed under a dissecting scope during the cleaning process, developed normally. However, a significant amount of additional work is still required to optimize the system and to prove its usefulness for long-term cultures of amphioxus larvae.

\section{Conclusion and perspectives}

Cephalochordates occupy a key phylogenetic position for understanding the evolutionary diversification of chordates and vertebrates, and efficient husbandry systems are crucial prerequisites for studying these important model organisms in a controlled laboratory environment. The protocols to induce on-demand spawning, to mature gonads, and to raise larvae through metamorphosis to adulthood hence represent major advancements for using cephalochordates as laboratory models. Although some of the described methods, such as the completion of the life cycle in captivity, still need further improvements, they have nonetheless already allowed a significant extension of the experimental amenability of different amphioxus species. Future work will have to address the husbandry shortcomings identified in this review, which include the dietary and environmental factors controlling larval development, metamorphic settlement, juvenile maturation as well as adult gonad formation and spawning. These aquaculture limitations are directly linked to the lack of information on cephalochordate ecology and behavior, highlighting the urgent need for studying these animals in their natural habitats. Nonetheless, given that husbandry methods are currently being developed for different amphioxus species (e.g. members of both the genus Branchiostoma and Asymmetron), the prospect of easy access to inter-phylum comparisons will undoubtedly increase the appeal of cephalochordates as model organisms in evolutionary and developmental biology

\section{Acknowledgements}

The authors are indebted to Hector Escriva from the Observatoire Océanologique de Banyuls-sur-Mer, France, for providing Branchiostoma lanceolatum adults and to Laurent Gilletta and Sophie Collet for help with maintaining amphioxus adults at the Observatoire Océanologique de Villefranche-sur-Mer, France. Elisabeth Zieger supported the data collection and commented the manuscript, and Estelle Hirsinger kindly read and revised the manuscript. We would also like to thank Tsuyoshi Momose for help with nursery tank development. This study was supported by a grant from the Agence Nationale de la Recherche (ANR-11-JSV2-002-01) and by funds from the Réseau André Picard (ANR-11-IDEX-0004-02, Sorbonne Universities) to Michael Schubert. João E. Carvalho was a FCT doctoral fellow (SFRH/BD/86878/2012).

\section{References}

ACEMEL RD, TENA JJ, IRASTORZA-AZCARATE I, MARLÉTAZ F, GÓMEZ-MARÍN C, DE LA CALLE-MUSTIENES E, BERTRAND S, DIAZSG, ALDEAD, AURY J-M, MANGENOT S, HOLLAND PWH, DEVOS DP, MAESO I, ESCRIVÁ H, GÓMEZSKARMETA JL (2016). A single three-dimensional chromatin compartment in amphioxus indicates a stepwise evolution of vertebrate Hox bimodal regulation. Nat Genet 48: 336-341.

ANDREWS EA (1893). An undescribed acraniate: Asymmetron lucayanum. Stud Biol Lab Johns Hopkins Univ 5: 213-247.

BENITO-GUTIÉRREZ È, WEBER H, BRYANT DV, ARENDT D (2013). Methods for generating year-round access to amphioxus in the laboratory. PLoSOne8: e71599.
BERTRANDS, ESCRIVAH (2011). Evolutionary crossroads in developmental biology: amphioxus. Development 138: 4819-4830.

BETTANY GT (1876). The missing link between the vertebrates and invertebrates. Nature 14: 195-196.

BOURLAT SJ, JULIUSDOTTIR T, LOWE CJ, FREEMAN R, ARONOWICZ J, KIRSCHNER M, LANDER ES, THORNDYKE M, NAKANO $\mathrm{H}$, KOHN AB, HEYLAND A, MOROZ LL, COPLEY RR, TELFORD MJ (2006). Deuterostome phylogeny reveals monophyletic chordates and the new phylum Xenoturbellida. Nature 444: 85-88.

CERFONTAINE P (1906). Recherches sur le développement de l'Amphioxus. Arch Biol Liège 22: 229-418.

CHEN Y, CHEUNG SG, SHIN PKS (2008). The diet of amphioxus in subtropical Hong Kong as indicated by fatty acid and stable isotopic analyses. J Mar Biol Assoc UK 88: 1487-1491.

CONKLINEG (1933). The development of isolated and partially separated blastomeres of Amphioxus. J Exp Zool 64: 303-375.

CONKLIN EG (1932). The embryology of amphioxus. J Morphol 54: 69-151.

COSTAOG (1834). Cenni zoologici ossia descrizione sommaria delle specie nuove di animali discoperti in diverse contrade del regno nell' anno 1834: con illustrazioni sopra talune altre meno ovvie. Azzolino E Comp, Napoli.

DELSUC F, BRINKMANN H, CHOURROUT D, PHILIPPE H (2006). Tunicates and not cephalochordates are the closest living relatives of vertebrates. Nature 439: 965-968.

DESDEVISES Y, MAILLET V, FUENTES M, ESCRIVA H (2011). A snapshot of the population structure of Branchiostoma lanceolatum in the Racou beach, France, during its spawning season. PLoS One 6: e18520.

ELEFTHERIOU A (Ed.) (2013). Methods for the study of marine benthos. John Wiley \& Sons, Oxford.

FUENTES M, BENITO E, BERTRAND S, PARIS M, MIGNARDOT A, GODOY L, JIMENEZ-DELGADO S, OLIVERI D, CANDIANI S, HIRSINGER E, et al., (2007). Insights into spawning behavior and development of the European amphioxus (Branchiostoma lanceolatum). J Exp Zool B 308: 484-493.

FUENTES M, SCHUBERT M, DALFO D, CANDIANI S, BENITO E, GARDENYES J, GODOY L, MORET F, ILLAS M, PATTEN I, et al., (2004). Preliminary observations on the spawning conditions of the European amphioxus (Branchiostoma lanceolatum) in captivity. J Exp Zool B 302: 384-391.

GOLDSCHMIDT R (1905). Amphioxides. In Wissenschaftliche Ergebnisse der Deutschen Tiefsee-Expedition auf dem Dampfer "Valdivia" 1898-1899. (Ed. C Chun). G. Fischer, Jena, pp. 1-90.

GRAY JE (1847). Description of a new species of amphioxus from Borneo. Ann Mag Nat Hist 19: 463-464.

HATSCHEK B (1893). The Amphioxus and its development, Ed. J Tuckey. Swan Sonnenschein \& Co., London, pp.181.

HENMIY, YAMAGUCHIT (2003). Biology of the amphioxus, Branchiostoma belcheri in the Ariake Sea, Japan I. Population structure and growth. Zoolog Sci20: 897-906.

HIRAKOW R, KAJITA N (1990). An electron microscopic study of the development of amphioxus, Branchiostoma belcheri tsingtauense: cleavage. J Morphol 203: 331-344.

HIRAKOW R, KAJITAN (1991). Electron microscopic study of the development of amphioxus, Branchiostoma belcheritsingtauense: the gastrula. JMorphol207:37-52.

HIRAKOW R, KAJITA N (1994). Electron microscopic study of the development of amphioxus, Branchiostoma belcheri tsingtauense: the neurula and larva. Kaibogaku Zasshi 69: 1-13.

HOLLAND LZ (2015). Cephalochordata. In Evolutionary developmental biology of invertebrates (Ed. A Wanninger). Springer, Vienna, pp. 91-133.

HOLLAND LZ, ALBALATR, AZUMI K, BENITO-GUTIÉRREZÈ, BLOWMJ, BRONNER FRASER M, BRUNET F, BUTTS T, CANDIANI S, DISHAW LJ, et al., (2008). The amphioxus genome illuminates vertebrate origins and cephalochordate biology. Genome Res 18: 1100-1111.

HOLLAND LZ, LAUDET V, SCHUBERTM (2004). The chordate amphioxus: an emerging model organism for developmental biology. Cell Mol Life Sci 61: 2290-2308.

HOLLAND LZ, YU J-K (2004). Cephalochordate (amphioxus) embryos: procurement, culture, and basic methods. Methods Cell Biol 74: 195-215.

HOLLAND ND (2011). Spawning periodicity of the lancelet, Asymmetron lucayanum 
(Cephalochordata), in Bimini, Bahamas. Ital J Zool 78: 478-486.

HOLLAND ND, HOLLAND LZ (1989). Fine structural study of the cortical reaction and formation of the egg coats in a lancelet (= amphioxus), Branchiostoma floridae (phylum Chordata: subphylum Cephalochordata=Acrania). BiolBull176: 111-122.

HOLLAND ND, HOLLAND LZ (2010). Laboratory spawning and development of the Bahama lancelet, Asymmetron lucayanum (Cephalochordata): fertilization through feeding larvae. Biol Bull 219: 132-141.

HOLLAND ND, HOLLAND LZ, HEIMBERG A (2015). Hybrids between the Florida amphioxus (Branchiostoma floridae) and the Bahamas lancelet (Asymmetron lucayanum): developmental morphology and chromosome counts. Biol Bull 228: 13-24.

HOWELLWM, BOSCHUNG HT (1971). Chromosomes of the lancelet, Branchiostoma floridae (order Amphioxi). Experientia 27: 1495-1496.

HUANG S, CHEN Z, YAN X, YU T, HUANG G, YAN Q, PONTAROTTI PA, ZHAO H, LI J, YANG P, et al., (2014). Decelerated genome evolution in modern vertebrates revealed by analysis of multiple lancelet genomes. Nat Commun 5: 5896 .

HUBBS CL (1922). A list of the lancelets of the world with diagnosis of five new species of Branchiostoma. Occas Pap Mus Zool Univ Mich 105: 1-16.

IGAWA T, NOZAWA M, SUZUKI DG, REIMER JD, MOROV AR, WANG Y, HENMI Y, YASUI K (2017). Evolutionary history of the extant amphioxus lineage with shallow-branching diversification. Sci Rep 7: 1157.

JIN P, LI S, SUN L, LV C, MA F (2017). Transcriptome-wide analysis of microRNAs in Branchiostoma belcheri upon Vibrio parahemolyticus infection. Dev Comp Immunol 74: 243-252.

KAJIT, HOSHINO Y, HENMI Y, YASUI K (2013). Longitudinal observation of Japanese lancelet, Branchiostoma japonicum, metamorphosis. Dataset Pap Biol2013: 1-6.

KON T, NOHARA M, NISHIDA M, STERRER W, NISHIKAWA T (2006). Hidden ancient diversification in the circumtropical lancelet Asymmetron lucayanum. Mar Biol 149: 875-883.

KONT, NOHARAM, YAMANOUEY, FUJIWARAY, NISHIDAM, NISHIKAWAT (2007). Phylogenetic position of a whale-fall lancelet (Cephalochordata) inferred from whole mitochondrial genome sequences. BMC Evol Biol 7: 127.

KOVALEVSKYAO (1867). Entwicklungsgeschichte des Amphioxus lanceolatus. Mém Acad Imp Sci St Pétersbourg 11: 1-17.

KUBOKAWA K, AZUMA N, TOMIYAMAM (1998). A new population of the amphioxus (Branchiostoma belcheri) in the Enshu-Nada Sea in Japan. Zoolog Sci 15:799-803.

KUBOKAWA K, MIZUTA T, MORISAWA M, AZUMA N (2003). Gonadal state of wild amphioxus populations and spawning success in captive conditions during the breeding period in Japan. Zoolog Sci 20: 889-895.

LI G, LIU X, XING C, ZHANG H, SHIMELD SM, WANG Y (2017). Cerberus-NodalLefty-Pitx signaling cascade controls left-right asymmetry in amphioxus. Proc Natl Acad Sci USA 114: 3684-3689.

LI G, SHU Z, WANG Y (2013). Year-round reproduction and induced spawning of Chinese amphioxus, Branchiostoma belcheri, in laboratory. PLoS One 8: e75461.

LI G, WANG J, YUAN L, WANG H, WANG Y-Q (2015). A simple method for selecting spawning-ready individuals out from laboratorial cultured amphioxus population. $J$ Exp Zool B 324: 629-635.

LI G, YANG X, SHU Z, CHEN X, WANG Y (2012). Consecutive spawnings of Chinese amphioxus, Branchiostoma belcheri, in captivity. PLoS One 7: e50838.

LIGHT SF (1923). Amphioxus fisheries near the University of Amoy, China. Science 58: $57-60$.

MOLLER PC, ELLIS RA (1974). Fine structure of the excretory system of Amphioxus (Branchiostoma floridae) and its response to osmotic stress. Cell Tissue Res 148: 1-9.

MOLLER PC, PHILPOTT CW (1973). The circulatory system of Amphioxus (Branchiostoma floridae) I. Morphology of the major vessels of the pharyngeal area. J Morphol 139: 389-406.

MOMOSE T (2010). Clytia. https://clytia.wikispaces.com/

NISHIKAWA T (1981). Considerations on the taxonomic status of the lancelets of the genus Branchiostoma from the Japanese waters. Publ Seto Mar Biol Lab 26: 135-156.

NISHIKAWA T (2004). A new deep-water lancelet (Cephalochordata) from off Cape Nomamisaki, SW Japan, with a proposal of the revised system recovering the genus Asymmetron. Zoolog Sci 21: 1131-1136.
NISHINO A, KUBOKAWAK, SEKIFUJI M, AZUMAN, MORISAWAM (1999). A survey of amphioxus (Cephalochordata: Branchiostoma belcheri) in the offing of Misaki. Benthos Res 54: 29-35.

OULION S, BERTRAND S, BELGACEM MR, LE PETILLON Y, ESCRIVA H (2012). Sequencing and analysis of the Mediterranean amphioxus (Branchiostoma lanceolatum) transcriptome. PLoS One 7: e36554.

PALLAS PS (1774). Spicilegia zoologica: quibus novae imprimis et obscurae animalium species iconibus, descriptionibus atque commentariis illustrantur. Vol 1, Fascicle 10. GA Lange, Berlin.

PAN M, YUAN D, CHEN S, XU A (2015). Diversity and composition of the bacterial community in amphioxus feces: amphioxus microbiome. J Basic Microbiol 55: 1336-1342.

PARIS M, ESCRIVAH, SCHUBERT M, BRUNETF, BRTKOJ, CIESIELSKIF, ROECKLIN D, VIVAT-HANNAH V, JAMIN EL, CRAVEDI J-P, SCANLAN TS, RENAUD J-P, HOLLAND ND, LAUDET V (2008). Amphioxus postembryonic development reveals the homology of chordate metamorphosis. Curr Biol 18: 825-830.

POSS SG, BOSCHUNG HT (1996). Lancelets (Cephalochordata:Branchiostomatidae): how many species are valid? Isr J Zool 42: S13-S66.

PUTNAM NH, BUTTST, FERRIERDEK, FURLONG RF, HELLSTENU, KAWASHIMA T, ROBINSON-RECHAVI M, SHOGUCHI E, TERRY A, YU J-K, et al., (2008). The amphioxus genome and the evolution of the chordate karyotype. Nature 453: 1064-1071.

RUPPERT EE, NASH TR, SMITH AJ (2000). The size range of suspended particles trapped and ingested by the filter-feeding lancelet Branchiostoma floridae (Cephalochordata: Acrania). J Mar Biol Assoc UK 80: 329-332.

SANDERS HL, HESSLER RR, HAMPSON GR (1965). An introduction to the study of deep-sea benthic faunal assemblages along the Gay Head-Bermuda transect. Deep Sea Res Oceanogr Abstr 12: 845-867.

SCHUBERT M, ESCRIVA H, XAVIER-NETO J, LAUDET V (2006). Amphioxus and tunicates as evolutionary model systems. Trends Ecol Evol 21: 269-277.

SOMORJAI IML, CAMASSES A, RIVIĖRE B, ESCRIVÀ H (2008). Development of a semi-closed aquaculture system for monitoring of individual amphioxus (Branchiostoma lanceolatum), with high survivorship. Aquaculture 281: 145-150.

SOMORJAI IML, ESCRIVÀ H, GARCIA-FERNÀNDEZ J (2012). Amphioxus makes the cut-again. Commun Integr Biol 5: 499-502.

STOKES MD, HOLLAND ND (1995). Embryos and larvae of a lancelet, Branchiostoma floridae, from hatching through metamorphosis: growth in the laboratory and external morphology. Acta Zool 76: 105-120.

STOKES MD, HOLLAND ND (1996). Life-history characteristics of the Florida lancelet, Branchiostoma floridae: some factors affecting population dynamics in Tampa Bay. Isr J Zool 42: S67-S86.

SUZUKI MM, SATOH N (2000). Genes expressed in the amphioxus notochord revealed by EST analysis. Dev Biol 224: 168-177.

TCHANG S, KOO KC (1936) Description of new variety of Branchiostoma belcheri (Gray) from Kiaochow Bay, Shantung, China. Contr Inst Zool Natl Acad Peking 3: 7-114.

TERAZAWA K, SATOH N (1997). Formation of the chordamesoderm in the amphioxus embryo: analysis with Brachyury and fork head/HNF-3 genes. Dev Genes Evol 207: 1-11.

THEODOSIOU M, COLIN A, SCHULZ J, LAUDET V, PEYRIERAS N, NICOLAS J-F, SCHUBERT M, HIRSINGER E (2011). Amphioxus spawning behavior in an artificial seawater facility. J Exp Zool B 316: 263-275.

TUNG TC, WU SC, TUNG YYF (1961a). Differentiation of the prospective ectodermal and entodermal cells after transplantation to new surroundings in amphioxus. Sci $\operatorname{Sin}$ 7: 253-262.

TUNG TC, WU SC, TUNG YYF (1961b). Experimental studies on neural induction in amphioxus. Sci Sin 7: 263-270.

TUNG TC, WU SC, TUNG YYF (1960). The developmental potencies of the blastomere layers in amphioxus egg at the 32-cell stage. Sci Sin 9: 119-141.

TUNG TC, WU SC, TUNG YYF (1958). The development of isolated blastomeres of amphioxus. Sci $\operatorname{Sin} 7:$ 1280-1320.

TUNG TC, WU SC, TUNG YYF (1963). The interchangeability of ectodermal and mesodermal cells in amphioxus. Sci Sin: 408-414.

URATA M, YAMAGUCHI N, HENMI Y, YASUI K (2007). Larval development of the 
Oriental lancelet, Branchiostoma belcheri, in laboratory mass culture. Zoolog Sci 24: 787-797.

WANG Y-Q, ZHANG Q-J, LU X-M, ZHONG J, SUNY (2006). Laboratory culturing and acquirement of the second filial generation of amphioxus. Zool Res 27: 631-634.

WICKSTEAD JH (1967). Branchiostoma lanceolatum larvae: some experiments on the effect of thiouracil on metamorphosis. J Mar Biol Assoc UK 47: 49-59.

WU SC, CAI NE (1964). Further studies on the interactions of various parts of the developing amphioxus egg. Shi Yan Sheng Wu Xue Bao: 119-129.

WU X, ZHANG B, GUO Z, QUY (2000). Artificial culture of amphioxus (Branchiostoma belcheri tsingtauense). Chin J Oceanol Limnol 18: 334-337.

YANG KY, CHEN Y, ZHANG Z, NG PK-S, ZHOU WJ, ZHANG Y, LIU M, CHEN J, MAO B, TSUI SK-W (2016). Transcriptome analysis of different developmental stages of amphioxus reveals dynamic changes of distinct classes of genes during development. Sci Rep 6: 23195.

YARRELL W (1836). A history of British fishes, I. J. Van Voorst, London.

YASUI K, IGAWA T, KAJI T, HENMI Y (2013). Stable aquaculture of the Japanese lancelet Branchiostoma japonicum for 7 years. J Exp Zoo B 320: 538-547.

YASUI K, URATA M, YAMAGUCHI N, UEDA H, HENMI Y (2007). Laboratory culture of the oriental lancelet Branchiostoma belcheri. Zoolog Sci 24: 514-520.
YONG LW, YU J-K (2016). Tracing the evolutionary origin of vertebrate skeletal tissues: insights from cephalochordate amphioxus. Curr Opin Genet Dev 39: 55-62

YU J-K, HOLLAND LZ (2009). Cephalochordates (amphioxus or lancelets): a model for understanding the evolution of chordate characters. Cold Spring Harb Protoc 2009: pdb.emo130.

YUAN S, RUAN J, HUANG S, CHEN S, XU A (2015). Amphioxus as a model for investigating evolution of the vertebrate immune system. Dev Comp Immunol 48: 297-305.

YUE J-X, KOZMIKOVA I, ONO H, NOSSA CW, KOZMIK Z, PUTNAM NH, YU J-K, HOLLAND LZ (2016). Conserved noncoding elements in the most distant genera of cephalochordates: the Goldilocks principle. Genome Biol Evol 8: 2387-2405.

YUE J-X, YU J-K, PUTNAM NH, HOLLAND LZ (2014). The transcriptome of an amphioxus, Asymmetron lucayanum, from the Bahamas: a window into chordate evolution. Genome Biol Evol 6: 2681-2696.

ZHANG Q-J, SUN Y, ZHONG J, LI G, LU X-M, WANG Y-Q (2007). Continuous culture of two lancelets and production of the second filial generations in the laboratory. $J$ Exp Zoo B 308: 464-472.

ZHANG Q-J, ZHONG J, FANG S-H, WANG Y-Q (2006). Branchiostoma japonicum and $B$. belcheri are distinct lancelets (Cephalochordata) in Xiamen waters in China. Zoolog Sci 23: 573-579. 


\section{Further Related Reading, published previously in the Int. J. Dev. Biol.}

From the American to the European amphioxus: towards experimental Evo-Devo at the origin of chordates Jordi Garcia-Fernàndez, Senda Jiménez-Delgado, Juan Pascual-Anaya, Ignacio Maeso, Manuel Irimia, Carolina Minguillón, Èlia BenitoGutiérrez, Josep Gardenyes, Stéphanie Bertrand and Salvatore D'Aniello Int. J. Dev. Biol. (2009) 53: 1359-1366 https://doi.org/10.1387/ijdb.072436jg

Evolution of CUT class homeobox genes: insights from the genome of the amphioxus, Branchiostoma floridae Naohito Takatori and Hidetoshi Saiga Int. J. Dev. Biol. (2008) 52: 969-977 https://doi.org/10.1387/ijdb.072541nt

Peter Holland, homeobox genes and the developmental basis of animal diversity Sebastian M. Shimeld Int. J. Dev. Biol. (2008) 52: 3-7 https://doi.org/10.1387/ijdb.072394ss

Developmental expression of the High Mobility Group B gene in the amphioxus, Branchiostoma belcheri tsingtauense

Xiangwei Huang, Lifeng Wang and Hongwei Zhang

Int. J. Dev. Biol. (2005) 49: 49-46

http://www.intjdevbiol.com/web/paper/041915xh

Cell morphology in amphioxus nerve cord may reflect the time course of cell differentiation T C Lacalli

Int. J. Dev. Biol. (2000) 44: 903-906

http://www.intjdevbiol.com/web/paper/11206331

Embryonic development of heads, skeletons and amphioxus: Edwin S. Goodrich revisited P W Holland

Int. J. Dev. Biol. (2000) 44: 29-34

http://www.intjdevbiol.com/web/paper/10761843

Amphioxus Hox genes: insights into evolution and development

$\mathrm{J}$ Garcia-Fernàndez and $\mathrm{P}$ W Holland

Int. J. Dev. Biol. (1996) 40: S71-S72

http://www.intjdevbiol.com/web/paper/9087701

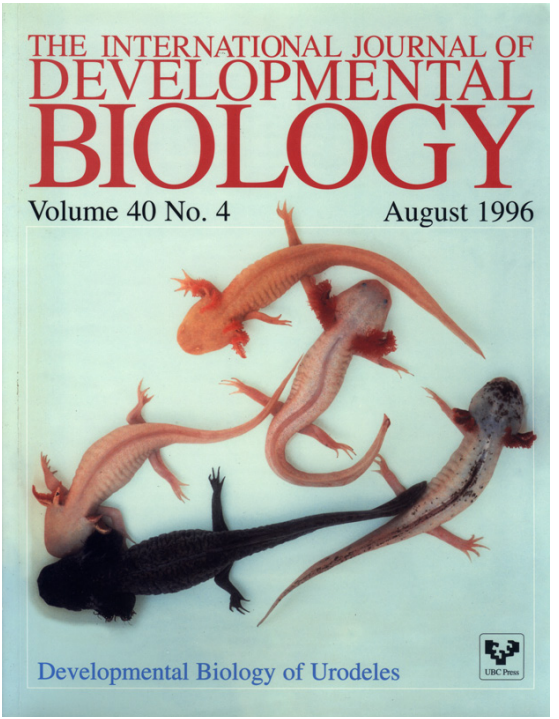

5 yr ISI Impact Factor $(2013)=2.879$
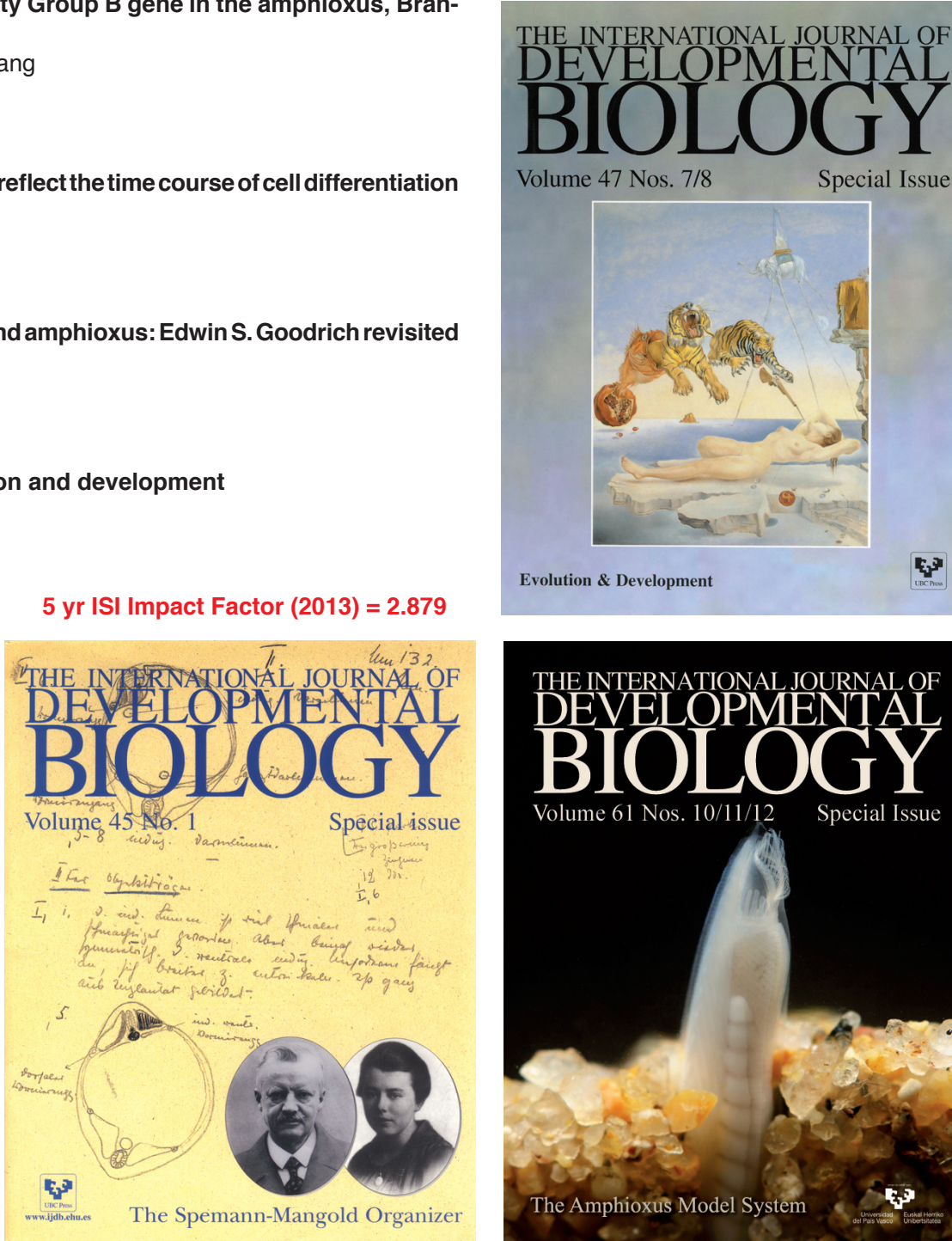

Volume 47 Nos. $7 / 8$ Special Issue

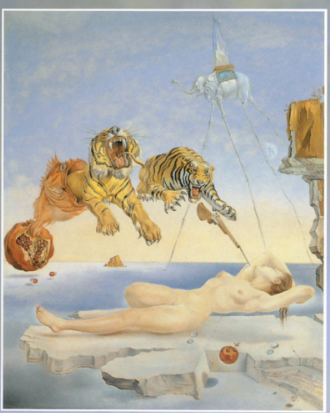

Evolution \& Development

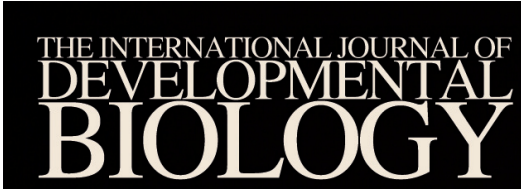

Volume 61 Nos. 10/11/12 Special Issue

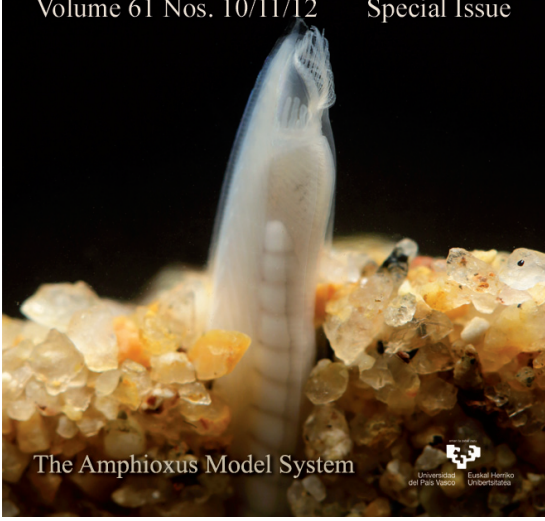

